\title{
GAMBARAN KUALITAS BAKTERIOLOGIS ANGKA LEMPENG TOTAL (ALT) PADA PENTOL GORENG DI SEKOLAH DASAR KECAMATAN BAROMBONG KABUPATEN GOWA
}

\author{
Haderiah $^{1}$, Nurindah Sari ${ }^{2}$ \\ 1,2, Jurusan Kesehatan Lingkungan Poltekkes Kemenkes Makassar \\ *) indah.nurindahsari02@gmail.com
}

\begin{abstract}
Fried Pentol is a designation for a type of meatball shaped snacks sold in front of elementary school. This makes it easy for fried pentol to be contaminated with the lowest bacteria with debris that perched on food (Pentol Goreng) bacteria is one of the causes of disease. The aim is to determine the presence of Total Plate Number (ALT) bacteria in fried pentol at the Primary School in Barombong District, Gowa Regency. This research is observational with a descriptive approach that will give an idea of the bacteriological quality of the Total Plate Numbers $(A L T)$ in fried pentol at the Elementary School of Barombong District, Gowa Regency. With a total sample of 7 fried pentol sellers. The results of this study with a total sample of 7 samples obtained only 6 samples of fried pentol that meet the requirements according to BPOM Number HK.00.06.1.52.4011 Concerning the Determination of Maximum Limits of Microbial and ChemicaContamination in Foodlt can be concluded that the laboratory tests that have been carried out on fried bulbs sold in Gowa Regency then obtained positive results containing the number of germs on fried bulbs. It is expected that all fried pentol sellers in Barombong Subdistrict Gowa Regency Elementary Schools maintain good hygiene and sanitation.
\end{abstract}

Keywords: Fried Pentol, Sanitation Hygiene, Total Plate Figures

\section{ABSTRAK}

Pentol goreng adalah sebutan untuk sejenis jajanan yang berbentuk bakso yang dijual di Depan Sekolah Dasar. Hal tersebut memudahkan pentol goreng terkontaminasi dengan bakteri yang terbawah dengan debuh yang hinggap dimakanan (Pentol Goreng) bakteri merupakan salah satu penyebab timbulnya penyakit. Tujuan untuk mengetahui keberadaan bakteri Angka Lempeng Total( $A L T)$ pada pentol goreng di Sekolah Dasar di Kecamatan Barombong Kabupaten Gowa. Penelitian ini merupakan observasional dengan pendekatan deskriptif yang akan memberikan gambaran tentang kualitas bakteriologis Angka Lempeng Total (ALT) pada pentol goreng pada Sekolah Dasar Kecamatan Barombong Kabupaten Gowa. Dengan jumlah sampel sebanyak 7 penjual pentol goreng. Hasil penelitian ini dengan jumlah sampel sebanyak 7 sampel diperoleh hanya 1 sampel pentol goreng yang memenuhi syarat menurut SNI 7388 tahun 2009 Tentang Batasan Maksimum Cemaran Mikroba Dalam Pangan. Dapat disimpulkan bahwa uji laboratorium yang telah dilakukan pada pentol goreng yang dijual di Kabupaten Gowa maka diperoleh hasil postif mengandung jumlah kuman pada pentol goreng. Diharapkan pada seluruh penjual pentol goreng yang ada di Sekolah Dasar Kecamatan barombong Kabupaten Gowa agar menjaga kebersiahan hygiene dan sanitasi dengan baik.

Kunci : Pentol Goreng, Hygiene Sanitasi, Angka Lempeng Total

\section{PENDAHULUAN}

Makanan yang dikonsumsi yang berasal dari jajanan bisa berpotensi menjadi makanan tidak aman dan bisa menyebabkan penyakit atau disebut dengan Food Borne disease.Food Borne disease bisa disebabkan oleh keracunan toksin atau bahan kimia yang berbahaya bagi tubuh, tetapi penyebab tersering Food Borne disease oleh bakteri, virus, dan parasit.

Makanan jajanan yang ada disekolah merupakan suatu kebutuhan yang harus tersedia disekolah sehingga dapat dikatakan bahwa makanan jajanan disekolah merupakan bagian yang penting dari sarana sekolah tersebut.Makanan jajanan diharapkan dapat mendukung upaya perbaikan gizi anak sekolah.Mengingat variasi makanan jajanan sangat beragam, harganya murah. Lebih dari $90 \%$ anak-anak usia sekolah kecuali TK ( taman kanak-kanak) tidak membawa bekal makanan dari rumah, sebagai ganti mereka dibekali uang untuk membeli makanan jajanan di sekolah (Depkes RI, 2006).

. Kondisi lingkungan dan perilaku penjamah jajanan tidak memenuhi syarat kesehatan. Rendahnya mutu hygiene makanan jajanan erat ikatannya dengan kebersihan lingkungannya, ketersediaan sarana, kondisi bahan baku, dan perilaku produsen/pedagang, serta tingkat pendidikannya. Tidak dapat dipungkiri penjamah makanan memegang peranan penting dalam menjamin keamanan makanan mulai dari pengolahan, penyimpanan.Penanganan yang keliru dan ketidak pedulian terhadapa cara-cara higienes dapat mempermudah bakteri pathogen kontak dengan makanan sehingga menimbulkan kontaminasi makanan yang dapat menyebabkan timbulnya penyakit pada saluran cerna misalnya diare yang disebabkan oleh bakteri Escherichia coli. 
Jurnal Sulolipu : Media Komunikasi Sivitas Akademika dan Masyarakat

Vol. 19 No.2 2019

e-issn : 2622-6960, p-issn : 0854-624X

Angka lempeng total merupakan metode kuantitatif yang digunakan untuk mengetahui jumlah mikroba pada suatu sampel

Pentol goreng adalah sebutan untuk sejenis jajanan yang berbentuk bakso dengan komposisinya tepung kanji saja di lumuri dengan telur. pentolan merupakan sejenis makanan jajanan yang terbuat dari tepung kanji yang dibentuk bulat lalu di rebus, dan digoreng dengan telur hingga matang, memiliki rasa gurih dan kenyal serta di sajikan dengan saus.karena harganya yang relatif murah, rasanya enak dan penampilan yang menarik maka jajanan ini sangat digemari terutama oleh anak-anak di Sekolah Dasar.

Pendidikan di Sekolah Dasar yaitu, untuk mewujudkan suasana belajar dan proses kegiatan pembelajaran dengan tujuan agar siswa secara aktif mengembangkan potensi dirinya untuk memiliki kekuatan spiritual keagamaan, pengendallian diri, kepribadian, kecerdasan, akhlak mulia, serta keterampilan yang diperlukan dirinya dan masyarakat, dalam berbangsa dan bernegara. Sehingga anak anak yang ada di Sekolah Dasar perlu dijaga jajanannya seperti pentolan.

\section{Langkah-langkah Penelitian}

Sampel dipipet secara aseptik sebanyak $10 \mathrm{ml}$ dalam botol steril yang didalamnya telah berisi sebanyak $90 \mathrm{ml} \mathrm{NaCl} \mathrm{0,9 \%} \mathrm{steril} \mathrm{lalu} \mathrm{di}$ homogenkan dengan cara dipipet keluar masuk sebanyak 25 kali, sehingga diperoleh pengenceran $10^{-1}$. Dipipet $1 \mathrm{ml}$ dari pengenceran $10^{-1}$ lalu dimasukkan ke dalam tabung pertama yang berisi $9 \mathrm{ml} \mathrm{NaCl} \mathrm{0,9 \%}$ steril dan homogenkan dengan cara memipet keluar masuk sebanyak 25 kali dalam tabung pertama disebut pengenceran $10^{-2}$. Di pipet $1 \mathrm{ml}$ tabung pertama dan dimasukkan ke dalam tabung kedua dan dihomogenkan dengan cara di pipet keluar masuk sebanyak 25 kali dan tabung kedua disebut pengenceran $10^{-3}$. Perlakuan yang sama dilakukan pada tabung ke dua sampai tabung kelima. Pada tabung ke lima dibuang sebanyak $1 \mathrm{ml}$ dan tabung ke enam tidak diisikan sampel sebagai control negative. Dipipet sebanyak $1 \mathrm{ml}$ dari pengenceran $10^{-1}$ dan dimasukkan kedalam cawan petri. Perlakuan yang sama dilakukan pemipetan dari $10^{-2}$ sampai pengenceran $10^{-6}$. Dituang media plate count agar sebanyak $15-25 \mathrm{ml}$ pada cawan petri yang telah berisi suspense sampel. Dituang plate count agar pada cawan petri yang kosong sebagai control negative. Setiap cawan petri tersebut diputar sedemikian rupa hingga membentuk angka delapan dengan tujuan menghomogenkan sampel dengan media. Setelah memadat, cawan diinkubasi pada $37^{\circ} \mathrm{C}$ selama 18-24 jam dengan sampel.

\section{Pengolahan Data}

Pengolahan data yang digunakan pada penelitian ini adalah dengan cara komputerisasi.

\section{HASIL PENELITIAN}

Penelitian ini bersifat observasional serta pemeriksaan laboratorium terhadap variabel terikat yang diteliti yaitu mengetahui Angka Lempeng Total pada pentol goreng yang dijual di Sekolah Dasar dan dilanjutkan data hasil pengamatan observasi lembar check list yang dilakukan di lapangan.

Berdasarkan hasil pemeriksaan di laboratorium, Angka Lempeng Total pada pentol goreng di SD Kec.Barombong Kab.Gowa dapat diliat dari pada tabel berikut:

\section{Tabel 1}

Kualitas baktriologis Angka Lempeng Total pada Pentol Goreng yang dijual di Sekolah Dasardi Kabupaten Gowa Tahun 2019

\begin{tabular}{|c|c|c|c|}
\hline No & Nama Sekolah Dasar & ALT & Keterangan \\
\hline 1 & SDI Kalukuang & $63.350 \mathrm{koloni} / \mathrm{gr}$ & Memenuhi syarat \\
\hline 2 & SDI Bontoa & 600 koloni/gr & $\begin{array}{l}\text { Tidak memenuhi } \\
\text { syarat }\end{array}$ \\
\hline 3 & SDI Tangalla & $28.400 \mathrm{koloni} / \mathrm{gr}$ & Memenuhi syarat \\
\hline 4 & SDN Moncobalang & $44.750 \mathrm{koloni} / \mathrm{gr}$ & Memenuhi syarat \\
\hline 5 & SDI Bontokarampuang & $30.900 \mathrm{koloni} / \mathrm{gr}$ & Memenuhi syarat \\
\hline 6 & SDI Bontoa 1 & 5750 koloni/gr & Memenuhi syarat \\
\hline 7 & $\begin{array}{l}\text { SDI Bontokarampuang } \\
1\end{array}$ & $22.750 \mathrm{koloni} / \mathrm{gr}$ & Memenuhi syarat \\
\hline
\end{tabular}

Berdasarkan Tabel 1 dapat dilihat bahwa hasil pemeriksaan ALT pada pentol goreng yang diperiksa yang berasal dari 7 sampel pentol goreng di Sekolah Dasar, terdapat 1 sampel yang tidak memenuhi syarat dan 6 sampel yang memenuhi syarat menurut BPOM Tentang Penetapan Batasan Maksimum Cemaran Mikroba dan Kimia, maka dapat di katakan bahwa 1 sampel pentol tersebut tidak layak untuk di konsumsi oleh anak Sekolah Dasar karena membahayakan kesehatan. 
Jurnal Sulolipu : Media Komunikasi Sivitas Akademika dan Masyarakat

Vol. 19 No.2 2019

e-issn : 2622-6960, p-issn : 0854-624X

Tabel 2

Hasil Observasi Hygiene sanitasi penjamah Pentol Goreng di Sekolah Dasar Kabupaten Gowa Tahun 2019

\begin{tabular}{|c|c|c|c|c|c|}
\hline No & Kriteria & $\mathrm{Ya}$ & $\%$ & Tidak & $\%$ \\
\hline 1 & $\begin{array}{l}\text { Saat menjamah pentol goreng } \\
\text { memakai pakaian yang bersih }\end{array}$ & 7 & 100 & 0 & 0 \\
\hline 2 & $\begin{array}{l}\text { Saat menjamah pentol goreng } \\
\text { yang tidak memakai celemek }\end{array}$ & 0 & 0 & 7 & 100 \\
\hline 3 & $\begin{array}{l}\text { Selalu memelihara kebersihan } \\
\text { tangan dan kuku }\end{array}$ & 4 & 57,1 & 3 & 42,9 \\
\hline 4 & $\begin{array}{l}\text { Tidak merokok } \\
\text { menjamah pentol goring }\end{array}$ & 2 & 28,6 & 5 & 71,4 \\
\hline 5 & $\begin{array}{l}\text { Tempat pengorengan pentol } \\
\text { dalam keadaan bersih }\end{array}$ & 7 & 100 & 0 & 0 \\
\hline 6 & $\begin{array}{l}\text { Tidak bercakap cakap atau } \\
\text { berbicara saat menjamah pentol } \\
\text { goreng }\end{array}$ & 2 & 28,6 & 5 & 71,4 \\
\hline 7 & $\begin{array}{l}\text { Saat menjamah makanan } \\
\text { menggunakan APD }\end{array}$ & 7 & 100 & 0 & 0 \\
\hline 8 & $\begin{array}{l}\text { Peralatan yang bersih disimpan } \\
\text { ditempat } \begin{array}{l}\text { yang } \\
\text { pencemaran }\end{array}\end{array}$ & 7 & 100 & 0 & 0 \\
\hline 9 & $\begin{array}{l}\text { Tidak batuk atau bersin didepan } \\
\text { makanan jajanan atau penyajian } \\
\text { atau tanpa menutup hidung dan } \\
\text { mulut }\end{array}$ & 7 & 100 & 0 & 0 \\
\hline & Total & 43 & 68.2 & 20 & 31,7 \\
\hline
\end{tabular}

Berdasarkan Tabel 3 diatas, diketahui bahwa penilaian dari hygiene sanitasi penjamah pentol goring yang memenuhi syarat sebanyak $68,2 \%$ dan yang tidak memenuhi syarat sebanyak $31,7 \%$

Tabel 3

Hasil Observasi Hygiene sanitasi penyajian pentol goreng di Sekolah Dasar Kabupaten Gowa tahun 2019

\begin{tabular}{c|c|c|c|c|c}
\hline No & Kriteria & Ya & $\%$ & Tidak & $\%$ \\
\hline 1 & $\begin{array}{l}\text { Tidak merokok pada saat } \\
\text { penyajian pentol goreng }\end{array}$ & 7 & 100 & 0 & 0 \\
\hdashline 2 & $\begin{array}{l}\text { Tidak berbicara pada saat } \\
\text { penyajian pentol goreng }\end{array}$ & 3 & 42,9 & 4 & 57,1 \\
\hdashline 3 & $\begin{array}{l}\text { Tidak batuk pada saat } \\
\text { penyajian pentol goreng }\end{array}$ & 4 & 57,1 & 3 & 42,9 \\
\hline & Total & 21 & 66,67 & 21 & 33,33 \\
\hline
\end{tabular}

Berdasarkan Tabel 3 diatas, diketahui bahwa penilaian dari hygiene sanitasi penyajian pentol goreng yang memenuhi syarat sebanyak $66,67 \%$ dan tidak memenuhi syarat $33,33 \%$

\section{PEMBAHASAN}

Untuk mencapai terjadinya makanan yang sehat maka upaya hygiene sanitasi makanan dan minuman harus berdasarkan prinsip upaya pengolahan bahan makanan, upaya untuk pengangkutan makanan, upaya penyampaian makanan dan upaya penyajian makanan (Mundiantun, Daryanto 2018).

Titik rawan dalam pengolahan makanan diantarannya adalah penjamah makanan. ini mempunyai hubungan erat dengan masyarakat konsumen sehingga penyebaran penyakit dapat terjadi melalui pengolahan makanan, baik dari perlengkapannya yang ada ditempat pengelolahan. Mikroba sama dengan makhluk hidup lainnya, yang memerlukan suplai nutrisi sebagai sumber energi dan pertumbuhan selnya. Kondisi tidak bersih dan hygiene pada lingkungan adalah kondisi yang meyediakannya sumber nutrisi bagi perumbuhan mikroba sehingga mikroba dapat tumbuh dan berkembang di lingkungan mikroorganisme dalam melangsungkan proses metabolisme dan berkembang biak membutuhkan sumber energi yang diperoleh oleh makanan.

\section{Kualitas bakteriologis Angka Lempeng Total terhadap Pentol Goreng yang dijual diSekolah Dasar Kabupaten Gowa}

Angka kuman atau angka lempeng total adalah angka menunjukkan adanya mikroorganisme pathogen atau non pathogen. Dari hasil uji laboratorium yang telah dilakukan pada pentol goreng yang dijual di Kecamatan Barombong Kabupaten Gowa maka diperoleh hasil positif mengandung jumlah kuman pada pentol goreng. hal tersebut dikarenakan dalam proses penyajian pentol goreng dilakukan di tempat terbuka yaitu di pinggir jalan yang dapat memungkinkan debu yang mengandung kuman hinggap di pentol yang telah di goreng

\section{Hygiene sanitasi penjamah pentol goreng terhadap bakteriologis Angka Lempeng Total}

Berdasarkan Tabel 2 diatas bahwa hasil observasi dilapangan dengan menggunakan lembar check list tentang persyaratan teknis penjamah pentol goreng dari 7 responden yang diwawancarai yang ada di Kabupaten Gowa dapat diliat tabel bahwa penjamah pentol goreng yang memenuhi syarat sebanyak $68,2 \%$ dan yang tidak memenuhi syarat sebanyak $31,7 \%$.

Hasil pengamatan observasi pada penelitian ini ada beberapa penjamah pentol goreng yang belum menerapkan personal hygiene dengan baik sebelum mengolah makanan sesuai responden yang telah 
Jurnal Sulolipu : Media Komunikasi Sivitas Akademika dan Masyarakat

Vol. 19 No.2 2019

e-issn : 2622-6960, p-issn : 0854-624X

dilakukan.pada tabel penjamah makanan yang tidak memenuhi syarat sebanyak $31,7 \%$.

Hasil pada penelitian ini terhadap responden yang telah di wawancarai penjamah pentol goreng saat menjamah pentol goreng memakai pakaian bersih, tidak memakai celemek, tidak memelihara kebersihan tangan dan kuku, responden masih ada yang merokok saat menjamah pentol goreng, responden masih ada yang bercakap cakap atau berbicara saat menjamah pentol goreng, tidak menggunakan APD, dan responden masih ada yang batuk atau bersin didepan makanan jajanan atau penyajian atau tanpa menutup hidung dan mulut.

\section{Hygiene sanitasi penyajian pentol goreng terhadap kualitas bakteriologis angka lempeng total}

Berdasarkan Tabel 3 diatas, bahwa hasil observasi dilapangan dengan menggunakan lembar check list tentang penyajian pentol goreng yang dijual di Sekolah Dasar di Kabupaten Gowa yang memenuhi syarat kesehatan ada 7 orang pedagang atau $(100 \%)$ yang tidak merokok pada saat penyajian pentol goreng. Ada 4 orang pedagang atau $(57,1 \%)$ tidak batuk saat penyajian pentol goreng. Dan sementara ada 3 pedagang atau $(42,9 \%)$ yang tidak berbicara pada saat penyajian pentol goreng

\section{KESIMPULAN}

1. Hygiene sanitasi penjamah pentol goreng di Kabupaten Gowa yang memenuhi syarat sebanyak $68,2 \%$ dan yang tidak memenuhi syarat sebanyak $31,7 \%$

2. Hygiene sanitasi penyajian pentol goreng di Kabupaten Gowa yang memenuhi syarat sebanyak $66,67 \%$ dan yang tidak memenuhi syarat sebanyak $33,33 \%$

\section{SARAN}

1. Diharapkan pada seluruh penjual pentol goreng yang ada di Sekolah Dasar Kecamatan barombong Kabupaten Gowa agar menjaga kebersiahan hygiene dan sanitasi dengan baik

2. BPOM (Badan Pengawasan hendaknya mengadakan penyuluhan tentang hygiene sanitasi untuk meningkatakan pengetahuan bagi para pedagang pentol goreng yang ada di Sekolah Dasar di Kecamatan Barombong.

\section{DAFTAR PUSTAKA}

Anwar. H Dkk.1987 Pedoman Bidang Studi Sanitasi Makanan dan Minuman pada Instansi Tenaga Sanitasi. Jakarta : Pusat Pendidikan Tenaga Kesehatan Depkes RI.

Aris Rivaldi wicaksono. 2016. Identifikasi Bakteri Escherichia coli dan shigella sp. Terhadap jajanan Cilok pada Lingkungan SD Negeri di Cirendeu, Pisang, dan Cempaka Putih.

Arisman. 2009. Buku Ajaran IImu Gizi Keracunan Makanan, Jakarta: EGC (online), https://repository. Uinjkt.ac.id, diakses tanggal 25 januari 2019.

Azrul Azwar, (1990). Pengantar Ilmu Kesehatan Lingkungan. Jakarta: PT. Mutiara Sumber Widya, cetakan pertama.

Departemen Kesehatan (2004). Tentang Hygiene Sanitasi Makanan dan Minuman (Online). http://reporsitory.usu.ac.id. Diakses pada tanggal 11 februari 2019.

Depkes. RI. 2006. Keamanan Pangan Jajanan Anak Sekolah Dasar, Departemen Kesehatan Rl, Jakarta (Online), https://repository.usu.ac.id, Diakses 24 januari 2019.

Entjang Indan (2001). IImu Kesehatan Masyarakat. Bandung: PT.Citra Aditya Bakti

Inayah dan Zaenab. 2017. Buku Panduan Pratikum Penyehatan Makanan Minuman. Makassar : Politeknik Makassar Jurusan Kesehatan Makassar. 
Jurnal Sulolipu : Media Komunikasi Sivitas Akademika dan Masyarakat

Vol. 19 No.2 2019

e-issn : 2622-6960, p-issn : 0854-624X

Moehji, Sjahmein. 2003. IImu Gizi 2 (penanggulangan Gizi Buruk). Jakarta : paparan sinar sinanti. (online), https://www.opac.unisayoga.ac.id, diakses 25 januari 2019.

Nataya Ani Isabella Purlianto (2015). Uji Angka Lempeng Total dan Identifikasi Escherichia coli jamu pahitan brotowali yang diproduksi oleh penjual jamu gendong keliling di wilayah tonggalan klaten tengah, (Online) https://repository.usd.ac.id. Diakses pada tanggal 11 Februari 2019.

Rusdin Rauf . 2013. Sanitasi Pangan \& HACCP. Yogyakarta: Graha IImu, cetakan pertama

Siti Fathona (2005). Hygiene dan sanitasi makanan. Semarang.Fakultas Teknik Universitas Semarang. (Online). https://eprints.ung.ac.id.Diakses 25 januari 2019.

SNI 7388, 2009. Tentang Batasan Maksimum Cemaran Mikroba (Online) (https://www.academia.edu/9959536/SNI 7388-2009 -

Batasan Maksimum Cemaran Mikroba dalam Pangan diakses pada tanggal 17 Juni 2019).

Sridianti. 2016. Pengertian bakteri . (online). (https://www.vebma.com di akses 25 januari 2019).

Sri Rejeki (2015). Sanitas hygiene dan K3 (kesehatan dan keselamatan kerja). Bandung : Rekayasa sains. 